\title{
Perubahan Perilaku Budaya dari Mburi Omah ke Ngarep Omah Masyarakat Pinggir Sungai
}

\section{Behavior Culture Changing of Mburi Omah to Ngarep Omah in Riverbank Society}

\author{
Afiarta Akbar Alfiyansyah \\ PT. Pertamina (Persero) Fuel Terminal Boyolali, Central Java \\ Alamat: Jl. Raya Boyolali-Semarang, Dusun II, Mojolegi, Teras, Boyolali, Central Java, \\ Indonesia 57372 \\ Email: afiartaakbaralfiyansyah2@gmail.com
}

\begin{abstract}
Abstrak
Tujuan penelitian ini mengungkap proses perubahan perilaku budaya masyarakat pinggir sungai ketika membuang sampah. Metode penelitian adalah etnografi dan pendekatan etnografi. Lokasi penelitian di Sungai Kalipepe Desa Tawangsari, Kabupaten Boyolali. Informan dipilih adalah warga desa yang tinggal di pinggir sungai lebih dari 5 tahun, kepala dusun, kepala desa, 8 orang dari warga desa yang tergabung dalam komunitas Wisnu Kencana, manajer Corporate Social Responsibility, anggota Tim CSR. Data dikumpulkan melalui observasi, observasi partisipasi dan wawancara mendalam kepada informan. Hasil penelitian ini menunjukkan masyarakat pinggir sungai Kalipepe mengalami perubahan perilaku budaya dari membuang sampah di sungai belakang rumah/mburi omah ke tempat sampah depan rumah/ngarep omah. Mereka merubah cara berpikir dan sistem budaya mburi omah ke ngarep omah untuk menjadikan Kalipepe sebagai destinasi wisata melalui proses panjang dari tahun 2017. Proses perubahan ini terjadi sesudah ada warga masyarakar pinggir sungai yang tergabung dalam kelompokkelompok sampai menjadi komunitas tidak membuang sampah ke Kalipepe. Kemudian warga terlibat dalam aktivitas kerjasama susur sungai komunitas lokal dan tim CSR. Susur sungai/tubing river dengan membersihkan sampah di sungai hingga sungai bersih sehingga layak dan dapat dinikmati wisatawan domestik.
\end{abstract}

Kata kunci: perubahan perilaku budaya, sampah, Sungai Kalipepe, mburi omah, ngarep omah, CSR, tubing river

\begin{abstract}
The purpose of this research is to reveal the process of changing the cultural behavior of the riverside community when disposing of garbage. The research method used ethnography and ethnographic approach. The research location is in the Kalipepe River, Tawangsari Village, Boyolali Regency. The informants selected were villagers who lived on the riverbank for more than 5 years, hamlet head, village head, 8 people from the village who are members of the Wisnu Kencana community, managers of Corporate Social Responsibility, members of the CSR Team. Data were collected through observation, participatory observation and in-depth interviews with informants. The results of this study indicate that the people on the edge of the Kalipepe river have experienced a change in cultural behavior from throwing garbage in the river behind the house / "mburi omah" to the trash in front of the house / "ngarep omah". They changed the way of thinking and the cultural system of "mburi omah" to "ngarep omah" to make Kalipepe a tourist destination through a long process from 2017. This change process occurred after residents of the riverbanks joined in groups to become a community that did not throw garbage at Kalipepe. Then the residents were involved in collaborative activities along the rivers of the local community and the CSR team. Tubing river is done by cleaning trash in the river until the it is clean so that is feasible and can be enjoyed by domestic tourists.
\end{abstract}

Keywords: cultural behavior change, garbage, Kalipepe River, mburi omah, ngarep omah, CSR, tubing rive

Biokultur, 2020, 9 (1): 48-61. DOI: http://dx.doi.org/10.20473/bk.v9i1.21721.

Article History:

Received August 31, 2020; Accepted September 22, 2020; Published Online September 23, 2020

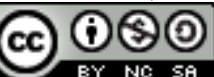




\section{Pendahuluan}

Berbagai hasil penelitian menunjukkan bahwa berbagai masyarakat mengalami perubahan sosial budaya karena pengaruh faktor eksternal, yaitu masuknya program dari pihak luar masyarakat. Selain itu ada perubahan sosial budaya masyarakat karena faktor internal, yaitu masyarakat sendiri yang ingin berubah.

Hasil penelitian terkait faktor eksternal ini diantaranya penelitian; Juliana (2015), bahwa program pembagunan telah merubah nilai sosial, perilaku, keorganisasian, institusi sosial, dan interaksi sosial, ekonomi masyarakat desa Tara-tara. Gunawan, Suryadi, Elly (2018), perubahan sosial budaya masyarakat pertanian dan perkebunan di Desa Wisata Cihideung, Cianjur karena pembangunan obyek pariwisata dan sarana pendukungnya. Perubahan sosial budaya yang terjadi antara lain: 1) berkurangnya interaksi sosial, 2) berkurangnya solidaritas sosial, 3) proses sosialisasi dipengaruh pihak luar desa, 4) berkurangnya pengawasan sosial dan kepedulian, 5) meningkatnya eksistensi kesenian, 6) mata pencarian yang heterogen dan 7) terjadi mobilitas sosial.

Yunita, Indrawati, Sahadi (2018), meneliti perubahan sosial pada Masyarakat Desa. Kebutuhan air bersih dipenuhi oleh PDAM yang menyediakan air bersih bagi masyarakat desa Genteng. Karena itu terjadi perubahan aturan dalam kelompok masyarakat desa terkait penggunaan air di desanya, mereka harus berbagi "sumber air" dengan PDAM. Pemanfaatan sumber air masyarakat desa oleh PDAM mendorong terjadinya perubahan sosial pada masyarakat desa Genteng. Perubahan tersebut terjadi karena hilangnya kontrol masyarakat desa atas sumber air yang menjadi sumber pengairan pertanian masyarakat desa yang membuat hilangnya basis produksi material masyarakat desa. Perubahan tersebut terjadi pada pola pertanian, mata pencaharian, relasi sosial dan struktur sosial masyarakat desa. Cahyono, (2016) meneliti pengaruh media sosial terhadap perubahan sosial masyarakat di Indonesia. Hasilnya bahwa media sosial adalah sebuah media online. Penggunanya dapat dengan mudah berpartisipasi, berbagi, dan menciptakan isi meliputi blog, jejaring sosial, wiki, forum dan dunia virtual. Blog, jejaring sosial dan wiki merupakan bentuk media sosial yang paling umum digunakan oleh masyarakat di seluruh dunia. Dampak positif dari media sosial adalah memudahkan penggunanya untuk berinteraksi dengan banyak orang, memperluas pergaulan, jarak dan waktu bukan lagi masalah, lebih mudah dalam mengekspresikan diri, penyebaran informasi dapat berlangsung secara cepat, biaya lebih murah. Sedangkan dampak negatif dari media sosial adalah menjauhkan orang-orang yang sudah dekat dan sebaliknya, interaksi secara tatap muka cenderung menurun, membuat orang-orang menjadi kecanduan terhadap internet, menimbulkan konflik, masalah privasi, rentan terhadap pengaruh buruk orang lain. Adanya media sosial telah mempengaruhi kehidupan sosial dalam masyarakat. Perubahan-perubahan dalam hubungan sosial (social relationships) atau sebagai perubahan terhadap keseimbangan (equilibrium) hubungan sosial dan segala bentuk perubahan-perubahan pada lembagalembaga kemasyarakatan didalam suatu masyarakat, yang mempengaruhi sistem sosialnya, termasuk didalamnya nilai-nilai, sikap dan pola perilaku diantara kelompokkelompok dalam masyarakat. Perubahan sosial positif seperti kemudahan memperoleh dan menyampaikan informasi, memperoleh keuntungan secara sosial dan ekonomi. Sedangkan perubahan sosial yang cenderung negatif seperti munculnya kelompok - kelompok sosial yang mengatasnamakan agama, suku dan pola perilaku tertentu yang terkadang menyimpang dari norma - norma yang ada. 
Faktor internal yang berpengaruh terhadap perubahan masyarakat, Andriati (2016) meneliti perubahan budaya kerja nelayan. Fluktuasi alam membuat budaya nelayan jadi terganggu, sehingga mereka tidak bisa pergi melaut. Para nelayan beralih pekerjaan menjadi pengemis, pemulung, dan pengamen. Para nelayan melakukan siasat manipulatif untuk memenuhi kebutuhan sehari-hari mereka. Laut yang tidak lagi menjajikan bagi nelayan membuat mereka beralih mencari pekerjaan yang lain. Sehingga memiliki budaya kerja selain menjadi nelayan dan melakukan politik kooperasi dengan bekerja di lahan lain selain di laut sebab laut tidak lagi menghasilkan ikan. Berdasar hasil penelitian tersebut, maka peneliti tertarik untuk meneliti lebih mendalam tentang perubahan perilaku budaya dari mburi omah ke ngarep omah masyarakat pinggir sungai Kalipepe. Apakah perubahannya karena faktor eksternal atau internal.

Desa Tawangsari merupakan salah satu desa yang berada di Kecamatan Teras Kabupaten Boyolali dengan masyarakat yang mayoritas orang jawa. Aktivitas masyarakat yang dilakukan biasanya berhubungan dengan pertanian, pertambangan dan perkebunan. Bentuk lahan di desa Tawangsari yang membuat masyarakat mayoritas menggunakan lahan untuk bertani. Selain itu yang berada di pinggiran sungai masyarakat kebanyakan melakukan penambangan pasir dan batu secara tradisional. Dalam komunikasi sehari-hari masyarakat dalam keluarga dan kegiatan di desa menggunakan bahasa Jawa kromo inggil dan bahasa Indonesia.

Kebudayaan menurut Koentjaraningrat (1998) merupakan serangkaian ide atau gagasan yang diwujudkan dalam norma dan aturan yang dipatuhi masyarakat dalam berperilaku dan bertindak yang didapatkan melalui proses belajar. Dalam suatu budaya terdapat 7 unsur kebudayaan yakni sistem bahasa, sistem pengetahuan, sistem peralatan hidup, sistem ekonomi, sistem organisasi, religi dan kesenian. Dari ketujuh unsur budaya tersebut diwujudkan dalam 3 hal yakni sistem ide, sistem sosial dan budaya fisik. Sistem ide merupakan inti dari suatu kebudayaan yang sangat sulit dirubah oleh masyarakat itu sendiri sebab merupakan pengetahuan tradisional yang melekat dalam diri masyarakat.

Letak Desa Tawangsari yang berada di dekat TBBM Boyolali membuat para community development officer Pertamina tertarik untuk melakukan corporate social responsibility di desa ini. Modal sosial yang ada di Desa Tawangsari memiliki potensi yang besar untuk dikembangkan menjadi suatu objek wisata. Masalah yang ada dalam masyarakat menjadi suatu pontensi pula bagi masyarakat untuk membuat Desa Tawangsari menjadi desa wisata. Masuknya tim CSR Pertamina membantu komunitas Wisnu Kencana dalam mengembangkan kegiatan di sungai dalam rangka melestarikan sungai yang tercemar. Para relawan telah berkegiatan terlebih dahulu sebelum Pertamina membantu dengan dana CSR perusahaan. Bantuan Pertamina dimulai dari tahun 2018 dengan memberikan perspektif baru mengenai pencegahan buang sampah di sungai melalui kegiatan wisata yang mana bantuan berupa peralatan operasional river tubing.

Fuel Terminal (FT) Boyolali merupakan bagian perusahaan PT. Pertamina (Persero) yang memiliki berbagai program pemberdayaan masyarakat dan pengolahan lingkungan sebagai wujud tanggung jawab perusahaan terhadap masyarakat sekitar perusahaan. Coorporate Social Responsibility (CSR) perusahaan terhadap kelestarian lingkungan diwujudkan dalam program keanekaragaman hayati dan pemberdayaan masyarakat di sungai Kalipepe. Pelestarian lingkungan sungai Kalipepe yang berdekatan dengan lokasi perusahaan tersebut disebabkan adanya pencemaran lingkungan sungai. Pencemaran tersebut bukan dikarenakan oleh perusahaan melainkan oleh masyarakat yang masih belum peduli akan kelestarian lingkungan. 
Teori Fungsional dari Talcott Parson yang digunakan untuk melihat perubahan sosial yang terjadi di masyarakat. Dimana masyarakat diibaratkan tubuh manusia yang saling berkaitan satu sama lain sebagai satu kesatuan sistem. Sistem yang dimaksud oleh Talcott Parson yakni adanya keharmonisan dan keutuhan fungsi yang saling koordinasi. Tubuh yang memiliki terbagi menjadi berbagai bagian dan memiliki fungsi masing-masing, sepertihalnya masyarakat yang mana antar lembaga saling berkaitan untuk menjaga keharmonisan masyarakat.

\section{Metode}

Metode penelitian ini menggunakan metode etnografi. Penelitian etnografi biasanya terdapat pertanyaan seperti bagaimana suatu masyarakat memaknai budaya mereka sebagai pembentuk tingkah laku keseharian mereka dan diinterpretasikan pula oleh mereka. Selanjutnya data dikumpulkan kemudian dilanjut dengan observasi dengan pertanyaan-pertanyaan yang bersifat deskriptif. Setelah itu dilanjutkan menganalisis data yang telah ditemukan di lapangan, dan pada tujuan akhirnya menulis etnografi setelah berhasil mengumpulkan data-data yang ada (Spradley 2007: 131). Peneliti melakukan observasi partisipasi dengan terlibat langsung dalam kegiatan - kegiatan komunitas Wisnu Kencana, baik dalam acara susur sungai dan sosialisasi masalah sungai bersama masyarakat setempat. Observasi lain yang dilakukan oleh peneliti adalah observasi mengenai perilaku membuang sampah warga pinggir sungai Kalipepe setiap hari dari sebelum, sedang dan pasca program pemberdayaan masyarakat/CSR dan kegiatan mereka sehari-hari. Observasi juga dilakukan pada aktivitas anggota Wisnu Kencana terkait program CSR di wilayah pinggir sungai Kalipepe ketika mereka menjaga lingkungan.

Informan dipilih secara purposive, yaitu warga desa yang tinggal di pinggir sungai lebih dari 5 tahun, kepala dusun, kepala desa, 8 orang dari warga desa yang tergabung dalam komunitas Wisnu Kencana, manajer Corporate Social Responsibility, anggota Tim CSR Wawancara mendalam dengan pedoman wawancara kepada 5 orang informan warga yang tinggal lebih dari 5 tahun di pinggir sungai Kalipepe. Pertukaran pemahaman antara peneliti dan informan terjadi. Wawancara berjalan santai dengan obrolan yang serius yang membuat informan tidak merasa seperti diinterogasi, melainkan seperti sedang berbincang dan bertukar cerita dengan seorang teman dekat. Saat inilah rapport peneliti dengan para informan terjalin. Wawancara mendalam juga kepada informan Kepala Dusun dan Kepala Desa Tawangsari, manajer CSR PT Pertamina.

Dalam meneliti mengenai komunitas Wisnu Kencana, peneliti menggunakan teknik pemilihan informan yang sudah banyak digunakan para peneliti-peneliti lain dalam menentukan informan yang dijadikan objek pengambilan data yaitu kriteria pemilihan informan dari James P. Spradley. Dalam memperoleh informan peneliti memilih berdasarkan rekomendasi dari ketua komunitas yang memahami betul kondisi dari komunitas beserta peran-peran dari para anggotanya, tentu saja tidak semua rekomendasi diterima namun dipilah lagi oleh peneliti berdasarkan keperluan pemilihan yang purposive, atau berdasarkan tujuan dari peneliti. Wawancara mendalam kepada 5 orang dari komunitas Wisnu Kencana yaitu komunitas yang sedang melakukan pemberdayaan masyarakat pinggir sungai Kalipepe. Gambaran awal tentang permasalahan penelitian bisa didapatkan, merujuk kepada penjelasan yang lebih mendalam tentang peran anggota Wisnu Kencana kepada warga masyarakat pinggir sungai. Lokasi penelitian berada di homebase Wisnu Kencana yakni ngebrak/basecamp Dusun Suko Desa Tawangsari, selain itu juga di lingkungan masyarakat Desa Tawangsari.

\section{Hasil dan Pembahasan}


Desa Tawangsari merupakan salah satu desa yang berada di Kecamatan Teras, Kabupaten Boyolali. Masyarakat Tawangsari banyak yang beraktivitas sebagai petani. Mereka memiliki lahan yang subur. Desa ini dilalui sungai sebagai sumber pengairan bagi kehidupan masyarakat. Desa Tawangsari memiliki berbagai program pemberdayaan yang bekerja sama dengan Corporate Social Responsibility PT. Pertamina (Persero) diantaranya ada Difabelfreuner, Camp Bell 2 Edupark, UMKM Karak, dan River Tubing/Susur Sungai Wisnu Kencana. Desa Tawangsari juga menjadi desa percontohan karena desa ini termasuk kedalam desa inovatif pada tahun 2017 yang lalu.

Di Desa Tawangsari terdapat sungai yang berada di sekitaran pemukiman warga, sungai ini di kenal dengan nama Kalipepe yang menjadi sumber penghidupan masyarakat. Masyarakat Tawangsari memiliki perspektif mengenai sungai, seperti dijelaskan oleh informan tokoh masyarakat bahwa

“...mereka menganggap bahwa sungai merupakan “mburi omah”/belakang rumah.

Barang tidak dipakai, sampah rumah ya dibuang ke sungai. Membuang sampah di belakang rumah ya di sungai itu. Sungai kan airnya mengalir terus, sampahnya ya ikut mengalir ke laut...tapi kadang air sungai kurang lancar. Hujan deras datang, sampah di sungai ikut jalan... Banyaknya masyarakat yang membuang sampah di sungai Kalipepe karena berada dibelakang rumah yang tidak terlihat oleh orang lain. Muncul mainset masyarakat mengenai sungai sebagai "mburi omah" yang mana masyarakat menganggap sungai sebagai tempat kotor membuang sampah...".

Mburi omah merupakan pemahaman masyarakat mengenai sungai bahwa berada di belakang rumah yang tidak memiliki manfaat. Adanya pemikiran masyarakat yang demikian membuat masyarakat Desa Tawangsari tidak dapat melihat potensi yang besar dari adanya sungai. Warga masyarakat yang akhirnya membuang sampah di sungai sebab adanya pemikiran bahwa sungai merupakan "mburi omah". Berdasar observasi peneliti, nampak kondisi sungai menjadi kotor. Selain itu sungai Kalipepe ini diekploitasi warga pinggir sungai dengan mengambil dan menjual pasir dan batu dari sungai untuk memenuhi kebutuhan hidup mereka.

Seperti yang diungkapkan informan Sarno (49) warga Desa Tawangsari:

"Kalipepe ini biasanya digunakan masyarakat untuk kehidupan sehari-hari, kebutuhan rumah tangga, pengairan sawah dan lain-lain. Masyarakat sini belum melihat manfaat sungai bagi ekonomi mereka. Selain itu sungai yang berada di mburi omah atau belakang rumah membuat warga dulu sering membuang sampah ke sungai”.

Pengetahuan lokal masyarakat Desa Tawangsari mengenai sungai, bahwa sungai merupakan "mburi omah". Mburi omah merupakan pemahaman masyarakat mengenai sungai bahwa berada di belakang rumah yang tidak memiliki manfaat. Adanya pengetahuan lokal ini membuat masyarakat Desa Tawangsari tidak dapat melihat potensi yang besar dari adanya sungai. Banyak masyarakat yang akhirnya membuang sampah di sungai. Pengetahuan lokal bahwa membuang sampah di belakang rumah tidak akan mempengaruhi ekonomi mereka sebab sungai masih dilihat sebagai sesuatu yang tidak memiliki dampak ekonomi. Hal tersebut membuat sungai menjadi kotor dan di ekploitasi untuk keberlangsungan hidup masyarakat sekitar sungai dengan menjual pasir dan batu sungai.

Selain itu kondisi pemukiman masyarakat yang berada di bantaran sungai dan tidak mempunyai tempat sampah, juga berakibat mereka sering membuang sampah ke sungai. Kebiasaan ini yang kemudian mengakibatkan sungai menjadi kotor dan jorok. Saat musim 
kemarau tiba, sampah di sungai sering menimbulkan bau yang tidak sedap dan menyengat warga pinggir sungai dan sekitarnya. Apalagi jika angin bertiup, bau tidak sedap makin menyebar.

Selain itu adanya aktivitas penambang pasir dan batu di sungai, mengakibatkan rusaknya ekosistem sungai. Informan kepala dusun dan kepala desa menjelaskan bahwa;

“...Kondisi penambangan pasir dan batu ini, jika tidak diantisipasi lebih dini maka kerusakan ekosistem bisa lebih parah. Hal ini tertanam dalam pemikiran masyarakat yang terus diwariskan dari generasi ke generasi. Banyak dari masyarakat menganggap bahwa tumpukan sampah yang menimbulkan bau yang tidak enak akan hilang ketika musim hujan tiba, sebab sampah-sampah tersebut akan hanyut terbawa arus banjir...".

Pengetahuan lokal masyarakat mengenai sungai tersebut merupakan bagian dari wujud kebudayaan yang pertama yakni sistem ide. Sistem ide ini merupakan pengetahuan lokal masyarakat yang melekat karena disosialisasi secara turun-menurun dari generasi ke generasi. Hal tersebut merupakan hasil konstruksi sosial yang akhirnya menjadi perilaku masyarakat dalam melihat dan memanfaatkan sungai. Konstruksi sosial menurut Luckman dan Berger merupakan realitas sosial yang diciptakan oleh individu yang secara bebas menentukan kehendaknya sehingga dapat membentuk suatu perilaku dalam masyarakat (Basrowi dan Sukidin 2002: 194). Dari sana diketahui bahwa perilaku manusia merupakan suatu hasil pembentukan pemikiran mengenai sesuatu hal oleh masyarakat dalam lingkungannya. Perilaku tersebut menjadi suatu kebudayaan seperti yang dijelaskan oleh Koentjaraningrat (1998) bahwa perilaku manusia didapat dari proses belajar di masyarakat dalam lingkungannya.

Dengan menggunakan dasar CSR triple buttom line yakni planet, pople dan profit diketahui bahwa pembangunan berkelanjutan yang dilakukan perusahaan tidak hanya berkonsentrasi pada isu-sisu lingkungan tetapi ada sisi sosial masyarakat dan keuntungan perusahaan. Seperti dijelaskan informan manajer CSR Pertamina bahwa:

“...Dalam program perbaikan lingkungan sungai melalui program wisata river tubing atau susur sungai dari Pertamina sebagai perusahaan dibidang energi menjadi pelopor perbaikan kerusakan lingkungan sungai. Perbaikan secara lingkungan tersebut didukung dengan adanya penanaman pohon di sekitar DAS Kalipepe. Selain itu Pertamina juga menggandeng kelompok relawan pecinta sungai. Kelompok ini yang kemudian di up skilling kemampuan menjadi guide wisata susur sungai yang menghasilkan keuntungan secara finansial bagi kelompok. Kegiatan tersebut bagian dari tujuan Pertamina dalam mensejahterakan masyarakat...".

Selanjutnya dijelaskan informan manajer CSR Pertamina bahwa:

“...Sungai yang seharusnya asri di daerah perdesaan menjadi kotor seperti sungaisungai di daerah perkotaan dengan banyaknya sampah-sampah plastik di sisi-sisi sungai. Sampah-sampah itu mengganggu aliran sungai ke area pertanian warga sehingga sering kali lahan sawah kekurangan air dan bahkan kotor dengan sampah plastik yang terbawa oleh aliran sungai. Selain itu penambangan liar yang dilakukan oleh warga setempat tanpa pengawasan membuat sungai tersebut menjadi semakin buruk. Itu sebabnya Pertamina dengan CSRnya berusaha mensosialisasi dan menyadarkan warga pinggir sungai agar tidak mbuang sampah di sungai lagi...".

Menurut informan Kepala Desa;

“...Sayangnya penambangan pasir dan batu terus terjadi. Ada 22 warga sekitar dan pinggir sungai yang setiap harinya menggunakan alat-alat yang masih tradisional 
menambang pasir dan batu. Puluhan truk ngangkut pasir dan batu tiap hari...lingkungan sungai rusak... mau dilarang ya repot, warga nggantungkan ekonomi keluarganya dari upah nambang itu...."

Penambangan di sekitaran sungai Desa Tawangsari begitu masif sehingga dapat merusak lingkungan sungai pada masa mendatang. Aktivitas penambangan dilakukan setiap hari yang menghasilkan batu dan pasir sampai puluhan truk dalam sehari.

\section{Perubahan Sosial Masyarakat Tepi Sungai}

Adanya kerusakan ekosistem sungai yang mulai dirasakan oleh masyarakat sekitar membuat beberapa warga yang peduli akan sungai di desanya. Kelompok ini berawal dari sekelompok bapak-bapak Desa Tawangsari yang memiliki rasa peduli akan sungai di Tawangsari, kemudian kelompok-kelompok ini menjadi suatu komunitas dengan memiliki tujuan yang sama. Mereka tergerak sebab melihat sungai yang semakin tercemar. Mereka menamakan komunitas ini Wisnu Kencana, yaitu suatu komunitas yang diharapkan dapat merangkul masyarakat pinggir sungai untuk peduli akan kebersihan sungai. Komunitas ini mulai membersihkan sungai dengan harapan sungai menjadi bersih dan lebih lestari.

Seperti yang diungkapkan ketua komunitas Wisnu Kencana Ibnu (51 tahun) sebagai berikut:

"komunitas ini dibentuk sebagai tindak lanjut terhadap adanya kerusakan lingkungan yang semakin parah. Warga masyarakat di luar desa yang melihat sungai kotor kemudian ikut membuang sampah ke sungai saat lewat jembatan sampah rumah tangga mereka di lempar ke sungai. Kebiasaan mbuang sampah di Kalipepe tidak hanya menggangu warga pinggir sungai tapi baunya kemanamana mencemari udara lingkungan Kalipepe dan sekitarnya. Kalipepe penuh sampah, dilihat juga menjijikkan”.

Kondisi ini dapat dilihat pada gambar berikut:

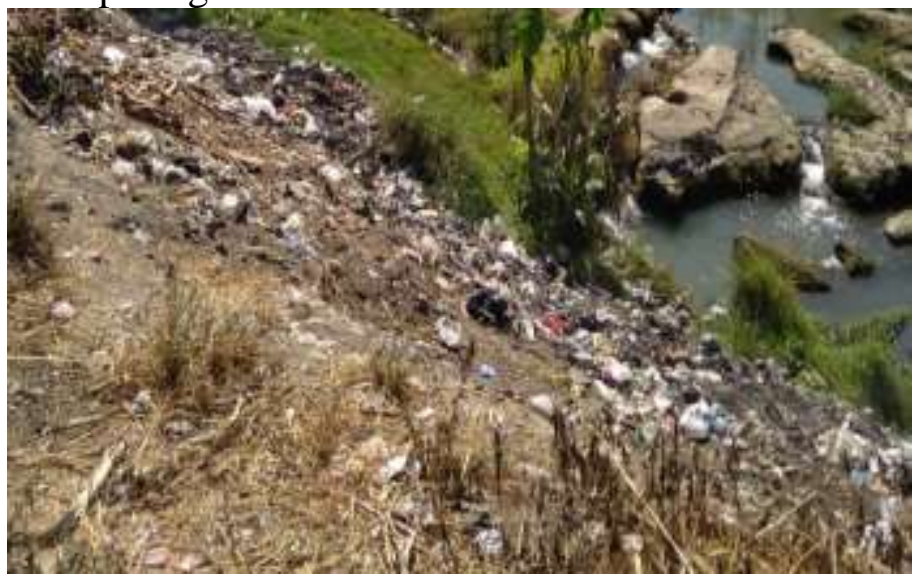

Gambar 1. Badan-badan sungai yang dipenuhi sampah rumah tangga

Sumber: Data Primer

Munculnya komunitas masyarakat peduli sungai tersebut sebagai respon atas perubahan yang muncul di masyarakat. Adanya ketidakseimbangan sistem yang terjadi di masyarakat membuat pembaharuan adaptasi pada lingkungan. Seperti yang diungkapkan Tallcot mengenai masyarakat seperti tubuh manusia yang merupakan seperangkat sistem sehingga jika ada yang tidak sesuai atau mulai membuat masyarakat tidak nyaman akan membuat perubahan.

Seperti yang diungkapkan informan Bapak Trijoko warga yang tinggal di pinggir sungai: 
"kalinya sudah gak sebagus dulu ditambah lagi kalo sampah numpuk sering bau. Selain itu aliran-aliran sungai ke daerah pertanian kadang sering mampet gara-gara sampah. Saya setuju sungai dibersihkan bersama... gotong royong, supaya sungai Kalipepe bersih. Warga mesti mbuang sampah di bak sampah, tidak boleh lagi mbuang sampah di sungai belakang rumah/mburi omah. Warga tidak boleh mbuang sampah pagi, siang, sore, malam baik diawasi atau tidak sama warga lain atau warga yang bertugas".

Keresahan tersebut yang mulai membuat masyarakat mulai sadar untuk tidak membuang sampah di sungai. Namun begitu jika ada warga yang masih membuang sampah ke sungai, maka warga lain sering memberi teguran agar tidak lagi membuang sampah ke sungai. Teguran ini dilakukan sesuai larangan kepala desa. Sering kali kemudian dilakukan ronda malam di dekat jembatan agar masyarkat tidak lagi membuang sampah ke sungai. Adanya kelompok ini membuat masyarakat takut jika membuang sampah di siang hari, padahal sebelumnya hal tersebut seperti kebiasaan membuang sampah kapanpun ke sungai. Terjadi perubahan perilaku di masyarakat dengan munculnya rasa malu jika ada yang melihat mereka melemparkan sampah ke sungai. Namun hal tersebut belum juga membuat sadar hanya mengubah rasa malu dan menimbulkan rasa takut, masyarakat kemudian membuang sampah di malam hari. Ini yang kemudian menjadi agenda selanjutnya komunitas Wisnu Kencana dengan menjaga sungai di malam hari, yang ternyata setelah dilakukan ronda malam jaga sungai hal ini sangat efektif untuk mengedukasi masyarakat.

Keresahan tersebut yang mulai membuat masyarakat mulai sadar untuk tidak membuang sampah di sungai. Namun begitu jika ada warga yang masih membuang sampah ke sungai, maka warga lain sering memberi teguran agar tidak lagi membuang sampah ke sungai. Teguran ini dilakukan sesuai larangan kepala desa. Sering kali kemudian dilakukan ronda malam di dekat jembatan agar masyarkat tidak lagi membuang sampah ke sungai. Adanya kelompok ini membuat masyarakat takut jika membuang sampah di siang hari, padahal sebelumnya hal tersebut seperti kebiasaan membuang sampah kapanpun ke sungai. Terjadi perubahan perilaku di masyarakat dengan munculnya rasa malu jika ada yang melihat mereka melemparkan sampah ke sungai. Namun hal tersebut belum juga membuat sadar hanya mengubah rasa malu dan menimbulkan rasa takut, masyarakat kemudian membuang sampah di malam hari. Ini yang kemudian menjadi agenda selanjutnya komunitas Wisnu Kencana dengan menjaga sungai di malam hari, yang ternyata setelah dilakukan ronda malam jaga sungai hal ini sangat efektif untuk mengedukasi masyarakat.

Langkah selanjutnya yang dilakukan para relawan komunitas Wisnu Kencana yakni dengan melakukan kegiatan susur sungai setiap minggu dengan agenda membersihkan aliran sungai akibat sampah rumah tangga yang menumpuk dipinggir dan badan sungai. Awal mereka lakukan dari tahun 2017 pertengahan dengan jumlah relawan 8 orang. Aktivitas kelompok ini kemudian terdengar oleh Tim CSR FT Boyolali yang kemudian dilakukan assessment kepada kelompok. Setelah mendapat informasi dan data yang cukup kemudian tercetuslah konsep wisata sungai yang memanfaatkan aliran deras sungai dan kedalaman air yang sedang saja. Komunitas Wisnu Kencana ini kemudian menjadi unit usaha dari Badan Usaha Milik Desa (BUMDes) Tawangsari sehingga pemerintah Desa dapat berkontribusi dengan peraturan desa mengenai pemanfaatan dan pelindungan sungai. 


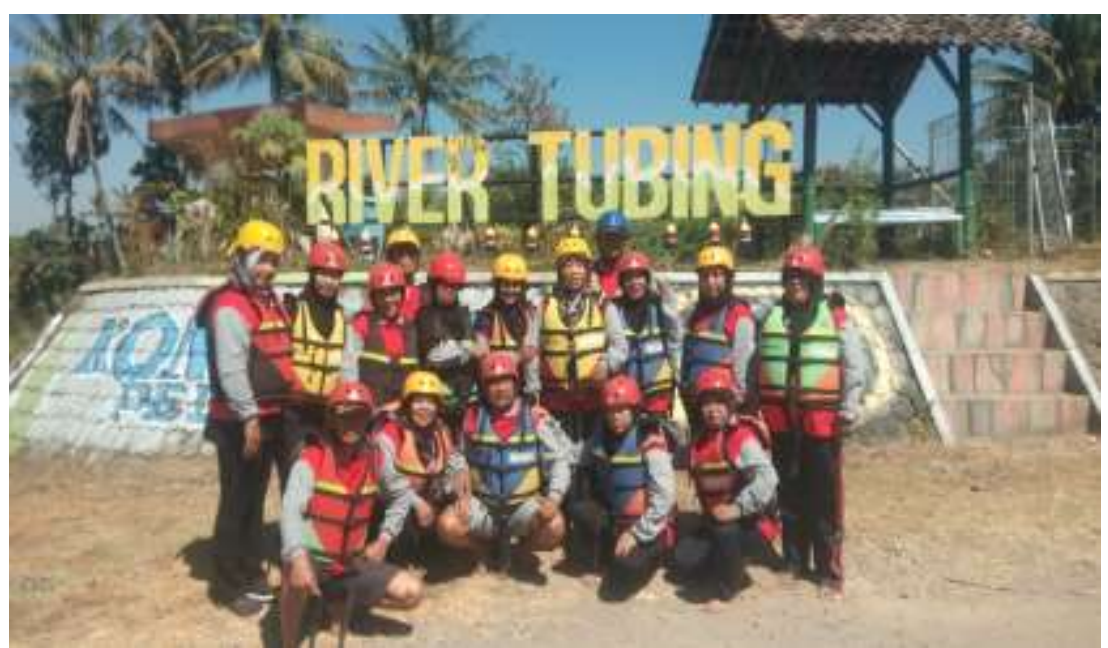

Gambar 2. Para Peserta River Tubing

Sumber: Data Primer

Keramaian wisata river tubing di Kalipepe semakin hari memperlihatkan peningkatan, pernah para relawan melakukan river tubing dari pagi hingga sore hari tanpa berhenti. River tubing sendiri yakni merupakan aktivitas susur sungai yang dilakukan dengan menggunakan ban mobil untuk dapat memanfaatkan aliran sungai yang deras. Kegiatan river tubing ini tidak dapat dilakukan kapan saja sebab harus memperhatikan cuaca agar selama susur sungai dapat lebih aman. Ada peserta river tubing yang ditolak akibat terlalu sore dan cuaca yang sudah mendung. Banyaknya kunjungan wisata di Kalipepe untuk kegiatan river tubing membuat masyarakat sekitaran bantaran sungai senang melihat aktivitas river tubing memiliki dampak ekonomi bagi mereka. Intensitas yang mulai sering dilakukan di Kalipepe membuat masyarakat bantaran sungai menjadi sungkan untuk membuang sampah ke sungai. Masyarakat secara sukarela membuat tampungan sampah untuk kemudian di integrasikan dengan TPST (Tempat Pengolahan Sampah Terpadu) yang ada di Desa Tawangsari.

Perubahan pada masyarakat perlahan-lahan memperlihatkan perilaku yang baru mengenai tindakan terhadap sungai. Sebelumnya masyarakat yang belum melihat nilai ekonomi dari sungai saat ini dengan adanya wisata mereka mulai sadar jika sungai bersih akan mendatangkan rejeki. Hadirnya komunitas pencinta sungai Wisnu Kencana menjadi bagian tidak terpisahkan dari perubahan perilaku masyarakat, agenda-agenda menjaga sungai dengan memberikan pengertian secara baik membuat perubahan perilaku masyarakat menjadi sangat alamiah yang tidak menimbulkan pergesekan di masyarakat. Pengaruh perubahan ini seperti yang diungkapkan Hanifah dkk dalam jurnal yang berjudul "Analisa Perubahan Sosial Budaya Masyarakat Desa Cihideung Sebagai Desa Wisata" bahwa adanya proses sosialisasi yang di pengaruhi oleh unsur dari dalam desa yaitu komunitas Wisnu Kencana dan luar masyarakat yakni adanya dukungan dari CSR PT. Pertamina (Persero) FT Boyolali, yang juga terlibat membuat wisata sungai dan mengakibatkan perubahan perilaku membuang sampah ke sungai.

Keramaian wisata river tubing di Kalipepe semakin hari memperlihatkan peningkatan, pernah para relawan melakukan river tubing dari pagi hingga sore hari tanpa berhenti. Selain itu juga ada peserta river tubing yang ditolak akibat terlalu sore dan cuaca yang sudah mendung. Banyaknya kunjungan wisata di Kalipepe untuk kegiatan river tubing membuat masyarakat sekitaran bantaran sungai senang menonton aktivitas river tubing. Intensitas yang mulai sering dilakukan di sungai Kalipepe membuat masyarakat bantaran sungai menjadi sungkan untuk membuang sampah ke sungai. Masyarakat secara sukarela membuat tampungan sampah untuk 
kemudian di integrasikan dengan TPST/Tempat Pembuangan Sampah Sementara yang ada di Desa Tawangsari.

\section{Dampak Positif Perubahan Sosial Masyarakat}

Dari program river tubing, terdapat beberapa dampak positif mulai dari Kalipepe Desa Tawangsari menjadi bersih, terdapat peningkatan keanekaragaman hayati, penambahan pendapatan kelompok dan desa. Kebersihan Kalipepe membawa berkah bagi penghidupan masyarakat yang dulu banyak sampah di sungai membuat sarang penyakit bagi masyarakat yang tinggal di bantaran atau pinggir sungai. Program ini telah mengubah kebiasaan/habit di masyarakat bantaran sungai yang menganggap bahwa sungai sebagai "mburi omah" menjadi "ngarep omah" dengan metode pendekatan wisata. Pendekatan wisata ini membuka pikiran masyarakat mengenai betapa berharganya sumber kekayaan alam seperti sungai Kalipepe jika dimanfaatkan dengan baik.

Diungkapkan informan Bambang (53 tahun) Relawan Wisnu Kencana;

"kali niku sumber panguripan dadi nek kaline resik, rejekine dadi apik"

"sungai itu sumber kehidupan, jadi jika sungainya bersih, rejeki jadi baik"

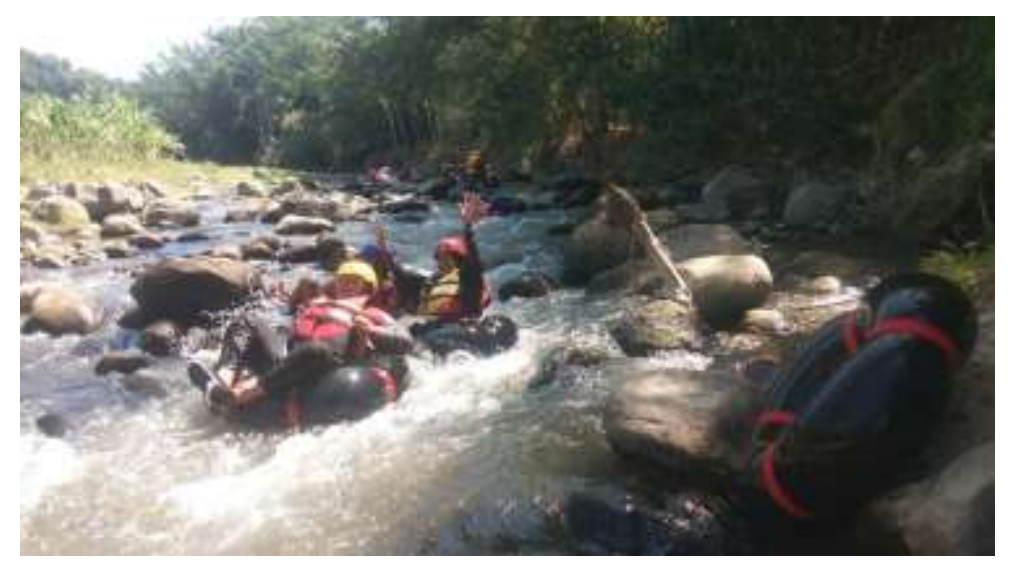

Gambar 3. Suasana Aktivitas River Tubing

Sumber: Data Primer

Kini wajah Kalipepe di Desa Tawangsari menjadi begitu indah dengan bantaran sungai yang bersih dan air sungai yang bersih jernih yang aliran airnya deras. Wajah baru Kalipepe ini menjadi salah satu bentuk program yang berdampak sosial ekonomi dan budaya lebih besar. Suatu kebudayaan yang telah tertanam sejak dulu sangat sulit untuk dirubah sebab mengubah suatu kebudayaan harus membuka ide atau gagasan yang ada di masyarakat. Tetapi dengan program wisata sungai ini masyarakat lebih mudah mengubah pola pikir mereka yang kemudian berdampak pada perubahan perilaku mereka. Perilaku awal membuang sampah ke sungai dikarenakan ide dan pengetahuan lokal mereka yang menganggap sungai sebagai tempat sampah. Namun demikian saat ini pengetahuan lokal mereka berubah dan beranggapan bahwa sungai sebagai sumber penghidupan masyarakat sehingga perilaku membuang sampah ke sungai sudah ditinggalkan. Hasilnya saat ini Kalipepe di Desa Tawangsari menjadi destinasi wisata di Boyolali yang memberi dampak sosial ekonomi dan budaya di masyarakat.

Salah satu pemuda yang ikut dalam komunitas Wisnu Kencana yakni Rian (17 tahun) mengatakan:

"merasa bangga menjadi bagian komunitas yang membuat sungai bersih kembali, seru ketika ada tamu yang berkunjung dan ingin mencoba susur sungai. Sekarang sungai bagi masyarakat bukan lagi mburi omah tetapi menjadi ngarep omah. Kegiatan susur sungai atau arung jeram ini menyenangkan dan stress hilang, segar pokoknya" 
Kebanggaan pemuda Desa Tawangsari ini karena perubahan sungai yang kini bersih dan lingkungan sungai menjadi sangat enak untuk dinikmati. Selain itu dampak positip untuk bidang sosial ekonomi dan budaya ke arah positip yang dirasakan masyarakat membuat perubahan perspektif yang ada dari sungai yang dianggap sebagai mburi omah saat ini menjadi ngarep omah. Hal ini memperlihatkan bahwa sungai harus dijaga dan dirawat, sebab sungai merupakan tampilan depan rumah bagi masyarakat jika terlihat kumuh mana mungkin pengunjung atau tamu akan mampir ke rumah mereka.

Kondisi lingkungan alam sungai yang sudah mendukung dan lingkungan sosial budaya masyarakat desa umumnya dan masyarakat pinggir sungai Kalipepe khususnya yang sudah berubah ini, relatif hamper sama dengan masyarakat Jawa umumnya. Sebagian masyarakat Jawa akan mempercantik bagian depan rumah mereka sebab hal tersebut memperlihatkan kepribadian penghuninya dan masyarakat Jawa percaya jika rumah terlihat indah dan bersih akan banyak rejeki yang akan datang kepada mereka.

Perubahan tersebut juga terjadi di awali oleh pengaruh dari luar. Pengaruh dari luar masyarakat seperti yang dilakukan oleh CSR PT. Pertamina (Persero) ini memiliki dampak yang sangat positif di masyarakat. Namun demikian tampak tanpa dorongan kesadaran dari masyarakat sendiri tidak akan mungkin perubahan itu terjadi, sehingga keterkaitan antara pihak ekternal dan internal menjadikan perubahan perilaku budaya yang masif di masyarakat. Perubahan perilaku budaya tidak membuang sampah ke sungai kembali membuat kawasan sungai di Desa Tawangsari menjadi bersih. Kebersihan area sungai ini membuat ketertarikan orang dari luar sebagai wisatawan domestik dating ke Desa Tawangsari untuk berkunjung dan mencoba river tubing atau susur sungai yang membuat mereka gembira.

Menurut informan Ketua sekaligus pengelola wisata River Tubing Wisnu Kencana Ibnu (51 tahun):

"setiap ada pengunjung yang melakukan river tubing minimal terjadi perputaran uang di kawasan wisata 00ini sebesar Rp 1.000.000,00 - Rp 3.000.000,00, terlihat dari hasil tiket masuk, pedagang yang hadir dan penjualan souvenir"

Sebagai suatu kawasan wisata, river tubing telah memiliki sistem yang sangat baik mulai dari pengelolaan kawasan sungai, penjualan makanan, souvenir dan lain sebagainya. Sistem kawasan wisata air ini menjadi sangat menarik kedepannya karena ada banyak perbaikan yang telah diberikan oleh CSR PT. Pertamina mulai dari infrastruktur dan kapasitas pengelola yang telah ditingkatkan kemampuan melayani tamu dan kemampuan menghadapi bencana di air.

Para relawan juga memiliki kegiatan edukasi sungai di mana membuka bagi masyarakat yang ingin mengetahui mengenai masalah sungai. Kemampuan relawan dalam kedaruratan sungai dan pengetahuan sungai tidak diragukan sebab para anggota telah mengikuti berbagai kegiatan penunjang seperti water rescue yang diselenggarakan CSR FT Boyolali bersama Tim SAR Boyolali. Sosialisasi dengan cara yang seru dan menarik menjadi salah satu cara memberikan pengetahuan terhadap masyarakat. Saat melakukan susur sungai dengan arum jeram ada penyisipan edukasi bagi pengunjung agar lebih menjaga lingkungan. Sesekali relawan mengadakan tanam pohon di pinggir sungai bersama anak-anak sekolah di sekitar desa, dengan begitu kegiatan akan lebih mudah dipahami oleh anak-anak. 


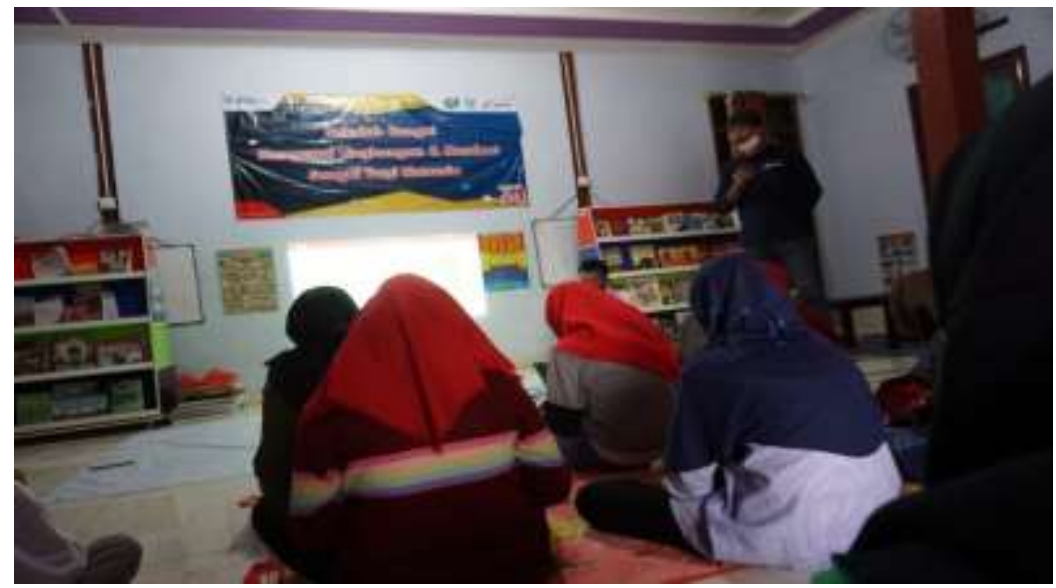

Gambar 4. Kegiatan Sekolah Sungai

Sumber: Data Primer

Saat ini komunitas Wisnu Kencana menjadi sasaran bagi pelajar-pelajar sekitar Desa Tawangsari untuk memperoleh pengetahuan mengenai lingkungan dan pelestariannya. Sisi edukasi yang diangkat dalam agenda Komunitas Wisnu Kencana ini juga menyasar anak-anak agar sejak dini dapat lebih sadar menjaga lingkungan alam sungai.

Komunitas Wisnu Kencana merupakan sekumpulan orang pecinta sungai yang ingin memperhatikan sungai. Kelompok ini memiliki aktor intelektual yakni Sumanto sebagai penggagas sekolah sungai. Menurut informan Sumanto (38 tahun):

"awal berdirinya komunitas sekolah sungai karena adanya keresahan di masyarakat bantaran sungai dengan tumpukan sampah yang menimbulkan bau. Kemudian mereka hanya membuat sosialisasi di masyarakat sambil melakukan razia sungai jika ada masyarakat yang membuang sampah ke sungai. Kemudian ternyata di BPBD Boyolali terdapat program sekolah sungai yang tujuannya merevitalisasi badan-badan sungai agar lingkungan sungai tidak rusak, ketika peresmian komunitas tersebut salah satu yang ikut diresmikan yakni komunitas wisnu kencana."

Masyarakat yang awalnya hanya membuat kumpulan untuk sosialisasi pelindungan lingkungan sungai yang kemudian berkembang hingga saat ini. Razia yang sering dilakukan bukan secara masif tetapi kondisional sehingga masyarakat hanya memberikan teguran bagi orang-orang yang membuang sampah ke sungai. Badan Penanggulangan Bencana Daerah (BPBD) Boyoalali memiliki program yang sangat sesuai dengan harapan masyarakat yakni sekolah sungai. Dari program BPBD ini kemudian komunitas Wisnu Kencana diberikan pelatihan peningkatan kapasitas kelompok pecinta sungai. Kegiatan di sungai kalipepe tiap bulannya yakni membersihkan badan sungai dari sampah-sampah yang menumpuk dan kemudian memberikan pemahaman kepada masyarakat bantaran sungai.

Selain itu juga adanya dukungan dari Pemerintah Desa Tawangsari dan CSR PT. Pertamina seperti yang diungkapkan informan Sumanto (38 tahun):

"Pemerintah Desa Tawangsari memberikan dukungan dengan membuatkan papan informasi larangan membuang sampah di sungai, sekaligus membuatkan aturan bagi masyarakat agar menjaga lingkungan. Selain itu Pemdes yang bekerja sama dengan CSR PT. Pertamina memperkenalkan komunitas wisnu kencana yang kemudian dilakukan pengoptimalan kelompok". 
Adanya dukungan dari Pemerintah Desa Tawangsari ini membuat komunitas bersemangat menjalankan agenda-agenda pemanfaatan lingkungan. Dukungan dari kebijakan yang dikeluarkan oleh Pemdes Tawangsari membuat mudah komunitas pecinta lingkungan Wisnu Kencana untuk melakukan sosialisasi dan memberikan tindakan dukungan bagi masyarakat. Pemerintah Desa Tawangsari memiliki visi membangun desa berbasis lingkungan sebab terdapat banyak masyarakat yang bergantung pada pertanian. Informan Kepala Desa Tawangsari yakni Yayuk TS (56 tahun) mengungkapkan:

"selama ini Pemdes tidak pernah memiliki program untuk memberdayakan masyarakat, adanya CSR di desa saya ini kemudian banyak memperlihatkan potensi desa yang tidak disadari oleh masyarakat. Pemdes memberi dukungan penuh untuk program lingkungan sebab sudah banyak masyarakat yang resah mengenai sampah yang dibuang di sungai. Selaku Pemdes mendukung melalui kebijakan dan mencari pendanaan untuk aktivitas wisata."

Masalah lingkungan di desa Tawangsari menjadi pokok perhatian sejak awal oleh Kepala Desa. Banyaknya masalah yang muncul di desanya membuat Yayuk selaku Kepala Desa mendukung penuh para relawan yang menjadi bagian penting dalam perbaikan lingkungan. Masyarakat yang secara sukarela peduli terhadap lingkungan menjadi sangat penting dalam agenda desa memperbaiki ekosistem lingkungan. Adanya laporan bahwa sampah-sampah yang terbawah arus Kalipepe masuk ke area persawahan membuat para petani kesulitan mengairi sawah mereka.

Tim CSR PT. Pertamina sebagai pendamping kelompok memberikan dampingan kepada masyarakat seperti yang diungkapkan informan Noor (26 tahun) sebagai pendamping CSR sejak 2017:

"awalnya program tersebut atas inisiatif masyarakat setempat, kita disini hanya memberikan bantuan dan pelatihan agar komunitas tersebut dapat meningkatkan kapasitas mereka. Selain itu sebagai perusahaan besar memiliki tanggung jawab terhadap lingkungan sekitar, hal tersebut yang membuat kita mendampingi kelompok Wisnu Kencana".

Sebagai perusahaan minyak terbesar di Indonesia PT. Pertamina memberikan bantuan CSR kepada masyarakat sekitar agar keseimbangan lingkungan tetap terjaga. CSR memberikan stimulus kepada kelompok Wisnu Kencana berupa bantuan perlengkapan operasional river tubing, dan pelatihan penunjang bagi komunitas agar cakap menghadapi masalah yang mungkin terjadi di sungai. Pendampingan tim CSR merupakan suatu kewajiban perusahaan agar masyarakat di sekitar perusahaan mendapat timbal balik yang positif dengan adanya perusahaan di lingkungan mereka.

Keterlibatan berbagai pihak dalam mengubah persepsi masyarakat bantaran sungai kalipepe dilakukan secara masif. Mulai dari kelompok pencinta lingkungan yang terbentuk secara swadaya masyarakat, pemerintah desa yang mendukung secara kebijakan, BPBD yang memiliki program sekolah sungai, dan tim CSR yang membantu peningkatan kapasitas komunitas. Pihak-pihak tersebut menbantu percepatan perubahan sosial di masyarakat bantaran sungai, membuang sampah ke sungai yang selama ini menjadi habit kemudian berubah menjadi perilaku yang positif. Masyarakat tidak lagi membuang sampah ke sungai bahkan dari mereka ada yang ikut pelestarian sungai dalam komunitas Wisnu Kencana. Pendekatan secara persuasif melalui berbagai kegiatan ternyata lebih dapat menyentuh masyarakat sehingga perubahan sosial tidak menimbulkan konflik. Melihat wisata sungai yang ramai tersebut warga menjadi sungkan dan bahkan malu untuk membuang sampah di sungai. 


\section{Simpulan}

Perubahan masyarakat yang terjadi pada masyarakat bantaran atau pinggir sungai Kalipepe Desa Tawangsari melalui proses panjang. Perubahan ini disebabkan oleh berbagai faktor baik secara internal dan maupun eksternal. Faktor internal yang membuat perubahan masyarakat bantaran sungai Kalipepe yakni munculnya rasa tidak nyaman akibat banyaknya sampah menumpuk di sungai, bau menyengat dan air sungai mampet. Munculnya kesadaran awal dari kelompok-kelompok kemudian menjadi komunitas warga yang mengajak dan mensosialisasi warga berubah membuang sampah dari 'mburi omah' ke 'ngarep omah'. Pengetahuan lokal mereka dirubah. Selain itu faktor eksternal yang berpengaruh adalah komunitas peduli sungai yang menggalakkan sosialisasi jaga sungai, intervensi CSR PT. Pertamina (Persero) dalam membuat dan melaksanakan wisata River Tubing, banyaknya pengunjung yang mulai berdatangan dan adanya Peraturan Pemerintah Desa Tawangsari yang melarang membuang sampah ke sungai. Kini Desa Tawangsari dengan wisata River Tubing menjadi daya tarik tersendiri bagi pengunjung yang ingin menikmati keindahan dan tantangan susur sungai. Sistem baru yang muncul dalam masyarakat membawa berkah bagi mereka untuk memperoleh tambahan pendapatan dari adanya perubahan perilaku mereka. Selain itu para penambang sudah mulai mengurangi aktivitas tambang dan sering terlibat dalam mendampingi pengunjung menyusuri sungai Kalipepe. Kaearifan lokal yang bertahan pasca operasional river tubing penting dikaji lebih lanjut.

\section{Daftar Pustaka}

Andriati R (2016) Perubahan Budaya Kerja Nelayan. Biokultur, 5 (1): 61-74.

Cahyono AS (2016) Pengaruh Media Sosial Terhadap Perubahan Sosial Masyarakat Di Indonesia. Publiciana, 9 (1): 140-157.

Gunawan H, Suryadi K \& Malihah Elly (2018) Analisis Perubahan Sosial Budaya Masyarakat Desa Cihideung sebagai Desa Wisata. Jurnal Sosietas, 5 (2).

Manuabu PIB (2008) Memahami Teori Konstruksi Sosial. Surabaya: Fakultas Ilmu Budaya Universitas Airlangga.

Koentjaraningrat (1998) Pengantar Antropologi. Jakarta: Gramedia.

Spradley JP (2007) Metode Etnografi. Yogyakarta: Tiara Wacana.

Yunita D, Sagita NI \& Sahadi Humaedi (2018) Perubahan Sosial Pada Masyarakat Desa: Tinjauan Materialisme Budaya dari Pemanfaatan Bersama Mata Air Pada Era Revolusi Industri 4.0 Universitas Padjajaran. Social and Political Challenges in Industrial 4.0. Proceeding Open Society Conference: 58-87. 